\title{
RESPONS FISIOLOGI KELINCI LOKAL YANG DIBERI RANSUM MENGGUNAKAN AMPAS TAHU YANG DISUPLEMENTASI RAGI TAPE PADA JENIS KANDANG BERBEDA
}

\author{
NURIYASA, I M., RONI, N.G.K., PUSPANI, E., CANDRAWATI, D.P.M.A., \\ WIRAWAN, I W. DAN PUGER, A.W. \\ Fakultas Peternakan, Universitas Udayana, Denpasar, Bali \\ e-mail: madenuriyasa@yahoo.com.
}

\begin{abstract}
ABSTRAK
Penelitian yang bertujuan mempelajari respon fisiologi kelinci jantan lokal telah dilakukan dengan menggunakan rancangan acak kelompok (RAK) pola split-plot $2 \times 3$ dengan 4 blok (ulangan). Jenis kandang sebagai main plot yang terdiri dari: kandang under ground shelter (Ko) dan kandang battery (K1). Perlakuan ransum sebagai sub plot yang terdiri dari: ransum tanpa menggunakan ampas tahu (Ro), ransum menggunakan 15\% ampas tahu tanpa suplementasi ragi tape (R1) dan ransum menggunakan 15\% ampas tahu yang disuplementasi o,2\% ragi tape (R2). Hasil penelitian mendapatkan bahwa kandang battery menyebabkan suhu dan kelembaban kandang lebih tinggi daripada kandangunder ground shelter. Temperatur dan kelembaban udara lebih tinggi pada K1 menyebabkan denyut jantung dan temperatur kulit lebih tinggi daripada Ko. Perlakuan ransum tidak berpengaruh nyata $(\mathrm{P}>0,05)$ terhadap temperatur dan kelembaban kandang serta temperatur rektal dan kulit ternak kelinci. Pada kandang Ko, perlakuan ransum tidak berpengaruh nyata terhadap laju respirasi. Pada kandang K1, perlakuan ransum R2 menyebabkan laju respirasi kelinci jantan lokal lebih tinggi daripada R1 dan Ro. Dari hasil penelitian dapat disimpulkan bahwa kelinci jantan lokal yang dipelihara pada kandang under ground shelter menghasilkan respon fisiologi lebih baik daripada kandang battery. Penggunaan ampas tahu dalam ransum kelinci dan suplementasi ragi tape pada penggunaan ampas tahu tidak mempengaruhi respon fisiologi ternak kelinci jantan lokal.
\end{abstract}

Kata kunci: kelinci lokal, temperatur, kelembaban udara, responfisiologi

\section{THE PHYSIOLOGICAL RESPONSES OF LOCAL RABBIT FED DIETS USING TOFU BY-PRODUCT SUPPLEMENTED WITH YEAST HOUSED IN TWO CAGE SYSTEM}

\begin{abstract}
An experiment was carried out to study the physiological responses of local rabbit fed diets using tofuby-product and supplemented with yeast and housed in two cage system. A split-plot design consists of two main plots: under ground shelter and battery housing system and three different diets as sub plot. The results showed that under ground shelter cage or Ko produced lower $(\mathrm{P}<0.05)$ temperature and humidity than the battery cage or K1 (Table 1). Lower temperature and humidity in under ground shelter cage than battery cage caused physiological responses better to rabbits. Diets without tofu by-product (Ro), diets using $15 \%$ tofu by-product (R1) and diets using $15 \%$ tofu by-product and supplemented with $0,2 \%$ yeast $(\mathrm{R} 2)$ did not give significant effect $(\mathrm{P}>0.05)$ to temperature, humidity, pulse rate, rectal temperature and skin temperature (Table 2). It was observed that there was a significant interaction $(\mathrm{P}<0.05)$ between cage system and ration on respiration rate (Table 3$)$. Diets did not have any significant effect $(\mathrm{P}>0.05)$ on respiration rate of the rabbit housed in under ground shelter cage. But converse was true for battery cage. Diets R2 caused significantly higher $(\mathrm{P}<0.05)$ respiration rate than R1 and Ro. It can be concluded that under ground shelter cage gave a better fisiological responds than battery cage. Different diets did not affect temperature and humidity. Further, diets without tofu by-product, diets using 15\% tofu by-product, using $15 \%$ tofu by-product and supplemented with $0.2 \%$ yeast did not give significant effect to rabbit fisiological response.
\end{abstract}

Keywords: local rabbit, temperature and humidity, physiological responses 


\section{PENDAHULUAN}

Pemeliharaan kelinci pada daerah-daerah yang beriklim panas akan mengalami permasalahan hampir sama seperti cekaman panas, kualitas pakan rendah dan mudah kena penyakit. Temperatur optimal untuk pertumbuhan ternak kelinci berkisar 9- $19^{\circ} \mathrm{C}(\mathrm{McNitt}$ et al., 1996) dan kelembaban relatif udara dalam kandang optimal 80- 86\% (Kamal et al., 2010). Menurut laporan BMKG (2010) daerah dataran rendah tropis mempunyai temperatur udara berkisar $21,87-31,13^{\circ} \mathrm{C}$ dan kelembaban relatif berkisar 79-86\%. Skriivanova et al., (2011) menyatakan kelinci termasuk ternak yang mengalami kesulitan untuk menyeimbangkan panas tubuhnya karena mempunyai kelenjar keringat sangat sedikit. Dalam kondisi cekaman panas, ternak kelinci akan meningkatkan laju respirasi dan denyut jantung.

Pengaruh negatif dari cekaman panas dapat diminimalkan melalui perbaikan faktor lingkungan termasuk makanan dan pemilihan jenis kandang yang lebih sesuai dengan lokasi peternakan (Nuriyasa, et al., 2010). Sistem pemeliharaan ternak kelinci dengan lantai tanah yang dilengkapi dengan lubang berlindung (underground shelter) menyebabkan temperatur udara rata-rata dalam lubang berlindung adalah $25,9^{\circ} \mathrm{C}$ dan kelembaban udara 80,4\% sedangkan temperatur udara dengan kandang battery adalah $29,4^{\circ} \mathrm{C}$ dan kelembaban udara 75,9\% (Suc et al., 1996).

Penggunaan limbah industri seperti ampas tahu sebagai pakan ternak merupakan salah satu solusi dalam usaha mitigasi pemanasan global dan menuju peternakan berkelanjutan (Dubey, 2007). Salah satu kelemahan limbah sebagai bahan pakan adalah kandungan serat kasar tinggi (Mastika, 2011). Proses biofermentasi pakan ternak yang bersumber pada limbah dapat menurunkan kandungan serat kasar pada bahan pakan tersebut. Penggunaan bioteknologi dibidang peternakan bertujuan untuk memanipulasi mikroorganisme dalam saluran pencernaan dengan memperbanyak mikroorganisme yang menguntungkan. Teknologi fermentasi adalah bagian dari bioteknologi yaitu memanfaatkan kemampuan mikroorganisme untuk melakukan transformasi senyawa organik melalui aktivitas metaboliknya (Dubey, 2007). Suplementasi ragi tape pada ransum komersial adalah langkah pemanfaatan teknologi fermentasi yang praktis dan mudah dilakukan oleh peternak.

\section{MATERI DAN METODE}

\section{Tempat dan Kandang Penelitian}

Penelitian dilaksanakan di Desa Dajan Peken Tabanan, yang terletak pada ketinggian tempat $50 \mathrm{~m}$ dari permukaan laut (dataran rendah). Kandang battery dan under ground shelter dibuat dengan ukuran panjang 70 $\mathrm{cm}$, lebar $50 \mathrm{~cm}$ dan tinggi $50 \mathrm{~cm}$.

\section{Ransum dan Air Minum}

Pakan ternak kelinci dibuat dalam bentuk pellet. Ransum perlakuan yang diberikan disusun berdasarkan rekomendasi dari McNitt (1996) yang terdiri dari bahan-bahan: jagung kuning, bungkil kelapa, tepung ikan, tepung tapioka, tepung kedelai, ampas tahu, dedak padi, rumput gajah, $\mathrm{NaCl}$, mineral mix, tepung tulang dan serbuk gergaji.Air minum berasal dari air PDAM Kabupaten Tabanan. Ransum dan air minum diberikan secara ad libitum.

\section{Rancangan Penelitian}

Penelitian dilaksanakan dengan rancangan acak kelompok (RAK) pola split plot $2 \times 3$ dengan 4 kelompok (ulangan). Faktor kandang (K) sebagai main plot yang terdiri dari kandang under ground shelter (Ko) dan kandang battery (K1). Faktor ransum(R) sebagai subplot yang terdiri dari: ransum Ro tidak menggunakan ampas tahu (kontrol) dengan kandungan energi termetabolis 2.609,39 kkal/kg dan protein kasar 15,94\%. Ransum R1 menggunakan ampas tahu 15\% tanpa suplementasi ragi tape dengan kandungan energi termetabolis 2.604,25 $\mathrm{kkal} / \mathrm{kg}$ dan protein kasar 16,06\%. R2 menggunakan ampas tahu $15 \%$ yang disuplementasi ragi tape $0,2 \%$ dengan kandungan energi termetabolis $2.604,25 \mathrm{kkal} /$ $\mathrm{kg}$ dan protein kasar 16,06\%.

\section{Variabel yang Diamati}

Pengamatan variabel temperatur dan kelembaban udara serta respon fissiologi dilakukan tiga kali sehari yaitu pada pukul 7.30, 13.30 dan 17.30 wita.

1. Temperatur dan Kelembaban Udara.Temperatur dan kelembaban udara diukur dengan menggunakan thermohygrometer digital tipe CE 11/o8.

2. Temperatur Rektal. Temperatur rektal diukur dengan termometer temperatur tubuh digital yang sensornya berbentuk bulat dan agak lancip dimasukkan ke dalam anus sedalam $6 \mathrm{~cm}$ selama satu menit (Kasa and Thwaites, 1993).

3. Temperatur Kulit. Temperatur kulit diukur dengan menggunakan thermohygrometer digital tipe CE 11/o8 dengan cara menempelkan sensor pada kulit kelinci. Pengukuran dilakukan pada empat titik yaitu kepala, leher, punggung dan pandat (Kasa and Thwaites, 1993).

4. Laju Respirasi. Laju respirasi diperoleh dengan menghitung gerakan naik turunnya permukaan rusuk-perut selama satu menit (Purnomoadi, 2003). Dalam pengambilan data ini diperlukan stopwatch yang digunakan sebagai penunjuk waktu dan hand tally counter untuk menghitung jumlah gerakan 
permukaan rusuk-perut. Satu gerakan naik (rusuk-perut mengembang) dan turun (rusuk perut mengempis) dihitung sebagai satu kali berespirasi

5. Denyut Jantung. Pengukuran denyut jantung dilakukan dengan cara menempelkan stetoskop akustik pada dada selama satu menit (Purnomoadi, 2003).

\section{Analisis Statistik}

Data yang diperoleh dianalisis dengan sidik ragam dan apabila diantara perlakuan menunjukkan perbedaan yang nyata $(\mathrm{P}<0,05)$ maka analisis dilanjutkan dengan uji Jarak Berganda Duncan (Steel dan Torrie, 1980).

\section{HASIL DAN PEMBAHASAN}

Denyut jantung kelinci lokal yang didapatkan dalam hasil penelitian berkisar 96,50 sampai 125,17 kali/menit (Tabel 1). Hasil penelitian ini masih berada dalam kisaran normal karena Kasa (1997) mendapatkan bahwa denyut jantung kelinci new zealand white yang dipelihara pada temperatur udara $21,1^{\circ} \mathrm{C}$ dengan $\mathrm{RH} 95 \%$ adalah $76 \mathrm{kali} /$ menit, sedangkan pada temperatur udara $35^{\circ} \mathrm{C}$ dengan $\mathrm{Rh} 95 \%$ adalah $421 \mathrm{kali} /$ menit.

Tabel 1. Temperatur, Kelembaban Kandang dan Respon Fisiologi Ternak Kelinci yang Dipelihara pada Kandang Berbeda.

\begin{tabular}{|c|c|c|c|}
\hline \multirow{2}{*}{ Variable } & \multicolumn{2}{|c|}{ Treatment } & \multirow{2}{*}{ SEM $^{3)}$} \\
\hline & $\mathrm{K} 0^{1)}$ & K1 & \\
\hline Temperatur Kandang $\left({ }^{\circ} \mathrm{C}\right)$ & $27,03^{\mathrm{b} 2)}$ & $28,88^{a}$ & 0,05 \\
\hline Kelembaban Kandang (\%) & $75,11^{b}$ & $76,94^{a}$ & 0,04 \\
\hline Denyut Jantung (kali/menit) & $96,5^{b}$ & $125,17^{a}$ & 1,72 \\
\hline Temperatur Rektal $\left({ }^{\circ} \mathrm{C}\right)$ & $39,06^{a}$ & $39,44^{a}$ & 0,05 \\
\hline Temperatur Kulit $\left({ }^{\circ} \mathrm{C}\right)$ & $37,08^{b}$ & $39,55^{a}$ & 0,29 \\
\hline
\end{tabular}

Keterangan:

1) K0: Kandang UnderGround Shelter

K1: Kandang Battery

2) Superskrip yang sama pada baris yang sama menunjukkan perbedaan tidak nyata $(P>0,05)$ dan superskrip berbeda pada baris yang sama menunjukkan perbedaan nyata $(P<0,05)$

3) SEM: Standard Error of the Treatment Means

Tabel 2. Temperatur, Kelembaban Kandang dan Respon Fisiologi Ternak Kelinci yang Diberi Ransum Berbeda.

\begin{tabular}{lrrrr}
\hline \multirow{2}{*}{ Variabel } & \multicolumn{3}{c}{ Perlakuan ${ }^{1}$} & \multirow{2}{*}{ SEM } \\
\cline { 2 - 4 } & \multicolumn{2}{c}{ R1 } & R2 & \\
\hline Temperatur Kandang $\left({ }^{\circ} \mathrm{C}\right)$ & $27,84^{\mathrm{a} 2)}$ & $28,01^{\mathrm{a}}$ & $27,90^{\mathrm{a}}$ & 0,06 \\
Kelembaban Kandang $(\%)$ & $74,79^{\mathrm{a}}$ & $74,95^{\mathrm{a}}$ & $74,96^{\mathrm{a}}$ & 0,09 \\
Denyut Jantung $(\mathrm{kali} / \mathrm{menit})$ & $107,53^{\mathrm{a}}$ & $116,18^{\mathrm{a}}$ & $120,47^{\mathrm{a}}$ & 4,23 \\
Temperatur Rektal $\left({ }^{\circ} \mathrm{C}\right)$ & $39,16^{\mathrm{a}}$ & $39,18^{\mathrm{a}}$ & $39,22^{\mathrm{a}}$ & 0,08 \\
Temperatur Kulit $\left({ }^{\circ} \mathrm{C}\right)$ & $37,89^{\mathrm{a}}$ & $38,46^{\mathrm{a}}$ & $38,28^{\mathrm{a}}$ & 0,25 \\
\hline
\end{tabular}

Keterangan:

1) RO: Ransum tanpa menggunakan ampas tahu (kontrol)

R1: Ransum menggunakan $15 \%$ ampas tahu tanpa suplementasi ragi tape

R2: Ransum menggunakan $15 \%$ ampas tahu yang disuplementasi $0,2 \%$ ragi tape.

2) Superskrip yang sama pada baris yang sama menunjukkan perbedaan tidak nyata $(P>0,05)$ dan superskrip berbeda pada baris yang sama menunjukkan perbedaan nyata $(P<0,05)$

3) SEM: Standard Error of the Treatment Means

Ternak kelinci yang dipelihara pada kandang battery (K1) menyebabkan denyut jantungnya lebih tinggi daripada kandang under ground shelter (Ko). Temperatur kandang pada $\mathrm{K} 1$ lebih tinggi $(\mathrm{P}<0,05)$ daripada kandang Ko $\left(28,88^{\circ} \mathrm{C}\right.$ vs $\left.27,03^{\circ} \mathrm{C}\right)$. Temperatur lebih tinggi pada kandang K1 menyebabkan penguapan yang bersumber dari air minum dan saluran pernafasan lebih tinggi sehingga kelembaban udara yang dihasilkan lebih tinggi $(\mathrm{P}<0,05)$ daripada kandang Ko $(76,94 \%$ vs. 75,11\%), seperti pada Tabel 1. Carvera dan Carmona (1998) menyatakan bahwa ternak kelinci sampai berumur 80 hari memerlukan temperatur udara optimum berkisar antara $15^{\circ} \mathrm{C}$ sampai $25^{\circ} \mathrm{C}$. Data temperatur dan kelembaban udara (Tabel 1) menunjukkan bahwa kelinci pada kandang K1 mengalami tingkat cekaman panas lebih tinggi daripada kandang Ko. Menurut Mount (1979) dan Mahardika (1990) dalam kondisi cekaman, ternak beradaptasi dengan cara mempercepat laju aliran darah dari dalam tubuh ke permukaan tubuh (kulit). Laju aliran darah dalam tubuh ternak akan membawa serta panas tubuh sehingga panas tubuh bisa sampai dipermukaan tubuh yang selanjutnya dilepaskan ke lingkungan dengan cara konveksi, konduksi, radiasi dan difusi dengan udara luar (boundry layer). Perlakuan ransum tidak berpengaruh terhadap denyut jantung kelinci jantan lokal. Hal ini disebabkan karena perlakuan ransum tidak berpengaruh terhadap temperatur dan kelembaban udara dalam kandang. Kasa (1997) menyatakan bahwa pada temperatur dan kelembaban udara yang sama, denyut jantung tidak berbeda.

Temperatur rektal mewakili temperatur seluruh bagian tubuh ternak karena merupakan hasil rata-rata pengukuran semua jaringan tubuh (Esmay, 1978). Panas pada tubuh ternak yang kemudian terukur sebagai temperatur tubuh ternak berasal dari panas metabolisme dan panas dari lingkungan. Hasil penelitian mendapatkan temperatur raktal rata-rata berkisar antara $39,06^{\circ} \mathrm{C}$ sampai $39,44^{\circ} \mathrm{C}$. Hasil yang sama didapatkan oleh Kasa dan Thwaites (1993) yaitu berkisar $39,4^{\circ} \mathrm{C}$ sampai $40,6^{\circ} \mathrm{C}$, Bivin dan King (1995) yaitu $39,5^{\circ} \mathrm{C}$.

Temperatur rektal pada ternak kelinci yang dipelihara pada kandang Ko tidak berbeda dengan kandang K1. Perbedaan temperature udara rata-rata diantara kandang Ko dan K1 tidak jauh berbeda yaitu sebesar $1,85^{\circ} \mathrm{C}$. Perbedaan temperatur tersebut belum berpengaruh pada temperatur rektal. Hasil penelitian yang sama didapatkan oleh Thwaites et al. (1990) yaitu kelinci yang dipelihara pada temperatur $34^{\circ} \mathrm{C}$ menyebabkan temperatur rektal $40,2^{\circ} \mathrm{C}$ yang tidak berbeda nyata dibandingkan dengan temperatur pemeliharaan $36^{\circ} \mathrm{C}$, temperatur rektalnya $40,7^{\circ} \mathrm{C}$. Perlakuan ransum berbeda tidak mempengaruhi temperatur rektal. Hal ini mengindikasikan bahwa perbedaan panas metabolisme dari perbedaan konsumsi ransum oleh ternak kelinci belum berpengaruh pada temperatur rektal.

Temperatur kulit rata-rata ternak kelinci jantan 
lokal berkisar antara $36,26^{\circ} \mathrm{C}$ sampai $39,97^{\circ} \mathrm{C}$. Hasil penelitian yang didapat masih dalam kisaran normal, sesuai dengan hasil penelitian Kasa dan Thwaites (1993) yaitu berkisar $34,43^{\circ} \mathrm{C}$ sampai $42,8^{\circ} \mathrm{C}$.

Temperatur kulit kelinci yang dipelihara pada Ko lebih rendah daripada kelinci pada kandang K1. Esmay (1978) menyatakan ternak yang mempunyai temperatur tubuh lebih tinggi dari temperatur lingkungan akan berusaha menyeimbangkan temperatur tubuhnya dengan lingkungan melalui cara konduksi, konveksi, radiasi dan evaporasi. Kelinci pada Ko yang berada di bawah lantaibangunan kandang menerima radiasi panas (gelombang panjang) lebih sedikit daripada K1. Hal ini menyebabkan temperatur rektal dan temperatur kulit lebih rendah. Disamping faktor tersebut, kandang under ground shelter yang dilengkapi lubang tempat berlindung akan memberi kesempatan pada ternak untuk melakukan proses homeostatis melalui mekanisme konduksi. Kontak badan dengan lantai kandang yang bertemperatur $25,12^{\circ} \mathrm{C}$ akan menyebabkan terjadi proses perpindahan panas secara konduksi dari kulit ke lantai kandang. Sebaliknya pada kandang battery proses konduksi tidak berjalan efektif karena temperatur lantai kandang $27,05^{\circ} \mathrm{C}$ mempunyai selisih temperatur yang kecil dibandingkan dengan temperature kulit. Makin tinggi selisih temperatur sumber dengan temperatur lingkungan maka proses perpindahan panas dengan cara konduksi makin tinggi. Temperatur kulit tidak dipengaruhi oleh perlakuan ransum berbeda. Temperatur kulit yang sama ini disebabkan karena perlakuan ransum tidak berpengaruh secara nyata terhadap variabel temperatur udara. Ternak dipelihara pada temperatur udara dalam kandang yang sama akan menghasilkan temperatur kulit yang sama pula, sesuai dengan pendapat Kasa dan Thwaites (1993).

Hasil penelitian mendapatkan laju respirasi kelinci jantan lokal berkisar antara 59,10 sampai 74,72 kali/ menit (Tabel 3). Laju respirasi yang didapat masih berada dalam kisaran normal, sesuai dengan yang didapat oleh Bivin dan King (1995) yaitu 32 sampai 60 kali/menit. Laju respirasi kelinci pada kandang K1 lebih tinggi daripada Ko. Mahardika (1990) dan Nuriyasa et al. (2010) menyatakan peningkatan laju respirasi adalah merupakan usaha ternak untuk mempercepat proses pelepasan panas dengan cara evaporasi dari saluran pernafasan. Lick dan Hung (2008) menyatakan bahwa kelinci mempunyai kulit dan bulu tebal sebagai insulasi panas sehingga pelepasan panas melalui proses penguapan dari kulit sangat kecil. Mempercepat laju respirasi adalah usaha paling efektip untuk menyeimbangkan panas tubuh. Pada kandang Ko, perlakuan ransum Ro, R1 dan R2 tidak berpengaruh pada laju respirasi ternak kelinci.
Tabel 3. Laju Respirasi Ternak Kelinci yang Dipelihara pada kandang Berbeda dan Diberikan Ransum Berbeda

\begin{tabular}{ccc}
\hline Ransum $^{11}$ & \multicolumn{2}{c}{ Kandang $^{2)}$} \\
\cline { 2 - 3 } & K0 & K1 \\
\hline \multirow{2}{*}{ R0 } & $59,10^{\mathrm{b} 3)}$ & $66,48^{\mathrm{a}}$ \\
& $\mathrm{A}$ & $\mathrm{C}$ \\
R1 & $58,93^{\mathrm{b}}$ & $68,95^{\mathrm{a}}$ \\
& $\mathrm{a}$ & $\mathrm{b}$ \\
R2 & $60,16^{\mathrm{b}}$ & $74,72^{\mathrm{a}}$ \\
& $\mathrm{a}$ & $\mathrm{a}$ \\
\hline
\end{tabular}

Keterangan:

1) RO: Ransum tanpa menggunakan ampas tahu (kontrol)

R1: Ransum menggunakan $15 \%$ ampas tahu tanpa suplementasi ragi tape

R2: Ransum menggunakan $15 \%$ ampas tahu yang disuplementasi $0,2 \%$ ragi tape.

2) KO: Kandang Under Ground Shelter

K1: Kandang Battery

3) Superskrip yang sama pada baris yang sama menunjukkan perbedaan tidak nyata $(P>0,05)$ dan superskrip berbeda pada baris yang sama menunjukkan perbedaan nyata $(P<0,05)$

Temperatur yang berada pada kisaran nyaman pada kandang Ko, menyebabkan proses homeostatis berjalan dengan baik sehingga perbedaan panas metabolisme dari perbedaan konsumsi ransum pada kelinci yang diberi perlakuan Ro, R1 dan R2 tidak mempengaruhi laju respirasi. Pada kandang K1, laju respirasi kelinci yang diberi perlakuan ransum $\mathrm{R} 2$ lebih tinggi $(\mathrm{P}<0,05)$ daripada R1 dan Ro. Iklim mikro yang berada di luar kisaran nyaman (hipertermia) pada kandang battery dan ditambah dengan beban panas metabolisme yang lebih tinggi pada R2 menyebabkan laju respirasi meningkat, seperti pada Tabel 3. Hasil penelitian ini didukung oleh penelitian Yan dan Li (2008) yang mendapatkan bahwa peningkatan temperatur lingkungan dari $20^{\circ} \mathrm{C}$ menjadi $35^{\circ} \mathrm{C}$ menyebabkan laju respirasi meningkat dari 40 $\mathrm{kali} /$ menit menjadi $200 \mathrm{kali} / \mathrm{menit}$.

Dapat disimpulkan bahwa (1) Kandang under ground shelter menyebabkan respon fisiologi kelinci jantan lokal lebih baik daripada kandang battery. (2) Penggunaan ampas tahu dan suplementasi ragi tape pada penggunaan ampas tahu tidak mempengaruhi respon fisiologi kelinci jantan lokal.

\section{SARAN}

Peternak disarankan menggunakan ampas tahu dalam ransum kelinci jantan lokal dan memilih kandang under ground shelter.

\section{UCAPAN TERIMAKASIH}

Penulis mengucapkan banyak terima kasih kepada LPPM Unud yang telah memberikan bantuan dana sehingga penelitian ini dapat terlaksana. 


\section{DAFTAR PUSTAKA}

Bivin, W.S. and King, W.W. 1995. Raising Healthy Rabbit. A Publication of Christian Veterinary Mission, Washington, USA.

BMKG. 2010. InformationWeather, Climate and Earth Quakes of Bali Province. Bulletin.Year No. III. September 9, 2009. Center for Meteorology, Climatology and Geophysics Agency Region III, Denpasar.

Carvera, C and Carmona, J.F. 1998. Climatic Environment. In: The Nutrition of the Rabbit. Ed. C. de Blas and J. Wiseman. CABI Publishing, New York.

Dubey, R.C. 2007. Biotechnology. S. Chand \& Company LTD, Ram Nagar, New Delhi.

Esmay, M.L. 1978. Principles of Animal Environment. Avi Publishing Company, Inc., Westport, Connecticut. p. 17-33.

Kamal, A., Yamani, dan Hassan, M. 2010. Adaptability of Rabbit to the Hot Climate. http://resource.ciheam.org/ om/pdf/c.08/95605280.pdf.

Kasa, I W. and Thwaites, C.J.. 1993. The Effect of Infra-Red Radiation on Rectal, Skin and Hair-Tip Temperatures of Rabbits. World Rabbit Science (1993), 1 (4), 133-138.

Kasa, I W. 1997. Effects of Various Environmental Temperature and Relatif Humidities on Physiological Responses of Rabbit. Anzslas Newsletter ISSN: 1039 - 0154.

Lick, N.Q. and Hung, D.V. 2008. Study and Design the Rabbit Coop Small-Scale Farm in Central of Vietnam. Department of Agriculture Engineering, Hue University of Agriculture and Forestry. Vietnam.

Mc.Nitt, J.I., Nephi, N.M., Lukefahr, S.D. and Cheeke, P.R. 1996. Rabbit Production. Interstate Publishers, Inc. p. 78-109.

Mahardika. I G. 1990. Penggunaan Lemak Sapi atau Minyak Kelapa sebagai Sumber Energi Pengganti Jagung untuk
Ayam Broiler. Tesis. Program Pascasarjana, IPB, Bogor. Mastika, I M. 2011. Potensi Limbah Pertanian dan Industri Pertanian serta Pemanfaatannya untuk Pakan Ternak. Penerbit: Universitas Udayana.

Mount, L. E. 1979. Adaptation to Thermal Environment, Man and His Productive Animal. Edward Arnold Publishing, London. P.1-12.

Nuriyasa, I M., Puspani, E., Sumatra, I G.N., Wibawa P.P., and Mudita, IM. 2010. Peningkatan Efisiensi Produksi Ayam Petelur Malaui Peningkatan Kenyamanan Kandang Di Desa Bolangan. Jurnal Udayana Mengabdi. Vol.9 No 2: 55-58.

Purnomoadi, A. 2003. Petunjuk Praktikum Ilmu Ternak Potong dan Kerja. Fakultas Peternakan, Universitas Diponegoro. http:// eprints.undip.ac.id./21200/1/1061ki-fp-05 pdf. Diakses 12 Nopember 2010.

Skriivanova, V., Marounek, M., Skriivan, M. and Knizek, J. 2011. Effect of Temperature on Growth, Feed Efficiency, and Mortality of Rabbits. Research Instutute of Animal Production, Parague-Unrineves.

Suc, Q. N. D.V., Binh, Ha, L.T.T. and Preston, T.R. 1996. Effect of Houshing System (Cage versus Underground Shelter) on Performance of Rabbits on Farm. Finca Ecologica, University of Agriculture and Forestry. Sumber: http://www.Irrd.org/Irrd8/4/cont 84.htm. Diakses 12 Nopember 2010.

Steel, R.G.D. and Torrie, J.H. 1980. Prinsip dan Prosedur Statistika. Suatu Pendekatan Biometrik. Edisi kedua. Diterjemahkan oleh Sumantri. Gramedia. Jakarta.

Thwaites, C.J., Bailllie, N.B. and Kasa, W. 1990. Effect of Dehydration on the Heat Tolerance of Male and Famale New Zealand White Rabbits. Journal of Agricultural Science. Cambridge (1990), 115: 437-440

Yan, Y. and Li, M. 2008. Feeding Management and Technology of Breeding Rabbit in Hot Climate. Qingdao Kanada Food Company Limited Kanada Group, Qingdao, 266400, China.Yanyk@vip.sina.com. 